Zabytkoznawstwo i Konserwatorstwo LII (2021)

\title{
Handel pigmentami miedziowymi ze złóż świętokrzyskich w świetle źródeł archiwalnych
}

\section{MICHAt WITKOWSKI}

Muzeum Pałacu Króla Jana III w Wilanowie

e-mail: mwitkowski@muzeum-wilanow.pl

ORCID: 0000-0003-3079-3833

\section{SYLWIA SVOROVÁ PAWEŁKOWICZ}

\section{Centrum Nauk Biologiczno-Chemicznych Uniwersytetu Warszawskiego}

e-mail: s.pawelkowicz@interia.pl

ORCID: 0000-0001-7872-5579

Keywords: trade in artists' pigments, malachite, azurite, Miedzianka, Miedziana Góra

Słowa kluczowe: handel materiałami artystycznymi, malachit, azuryt, Miedzianka, Miedziana Góra

\begin{abstract}
Trade in Copper Pigments from Świętokrzyskie Deposits in the Light of Archival Sources

The old Kingdom of Poland had two significant centres for copper ores exploitation in the region of Świętokrzyskie Mountains: Miedzianka, located in the mountain range of Chęciny, and Miedziana Góra, now situated in the urban agglomeration of Kielce. The article addresses the $16^{\text {th }}$ and $17^{\text {th }}$-century trade in copper pigments (azurite, malachite, and verdigris) obtained from the deposits mentioned above. As for archival sources, information about trade in art supplies appears in legal documents regarding mining towns' privileges and in financial records, such as the accounts of the royal court and of the court of Cracow bishops, in surveys of royal estates, as well as surveys
\end{abstract}


of the landed property of Cracow bishops and of the Cracow Cathedral Chapter. The study of the few remaining copies of books of the Chęciny mine governor (zupparius) and of the city records, where details about both the sellers and their debtors can be found, provided valuable information about the mines' operations. The data collected indicate that pigments from Świętokrzyskie Mountains deposits were used for the decorations of the Wawel Castle in Cracow and the Royal Castle in Warsaw, as well as for the decorations of the Castle of the Grand-Duke in Vilnius, and that some pigments, e.g., malachite, were exported to Western Europe.

\begin{abstract}
Abstrakt
W regionie geograficznym Gór Świętokrzyskich, w pobliżu Kielc, znajdowały się dwa ważne w okresie staropolskim ośrodki wydobycia rud miedzi w Polsce - położona w Paśmie Chęcińskim Miedzianka oraz leżąca w obecnej aglomeracji kieleckiej Miedziana Góra. Artykuł porusza zagadnienie handlu pigmentami miedziowymi (azurytem, malachitem i grynszpanem) pochodzącymi z tamtejszych złóż na przestrzeni XVI-XVIII w. W źródłach archiwalnych informacje na temat handlu materiałami artystycznymi pojawiają się w dokumentach prawnych dotyczących przywilejów górniczych oraz aktach gospodarczych, w tym rachunkach dworów królewskich i biskupich, a także lustracjach dóbr królewskich i majątków biskupstwa krakowskiego oraz krakowskiej kapituły katedralnej. Cenne wiadomości o funkcjonowaniu kopalń pozyskano również z fragmentarycznie zachowanych w odpisach chęcińskich ksiąg żupniczych oraz akt miejskich, gdzie zawarte są także szczegóły dotyczące zarówno sprzedawców, jak i ich dłużników. Zebrane informacje wskazują, że pigmenty ze złóż świętokrzyskich wykorzystywano do dekoracji zamków królewskich w Krakowie i Warszawie oraz zamku wielkoksiążęcego w Wilnie, a niektóre z nich, takie jak np. malachit, eksportowano do Europy Zachodniej.
\end{abstract}

W okresie staropolskim dwa główne obszary pozyskiwania rud metali szlachetnych i kolorowych oraz towarzyszących im minerałów znajdowały się w okolicach Kielc, w Miedziance i Miedzianej Górze. W kontekście handlu materiałami artystycznymi wymienić należy malachit, $\mathrm{Cu}_{2}\left(\mathrm{CO}_{3}\right)(\mathrm{OH})_{2}$, oraz azuryt, $\mathrm{Cu}_{3}\left(\mathrm{CO}_{3}\right)_{2}(\mathrm{OH})_{2}$ - naturalnie występujące w przyrodzie zasadowe węglany miedzi, powszechnie stosowane w sztuce dawnej jako pigmenty malarskie, odpowiednio o barwie zielonej i niebieskiej. Ponieważ są to minerały wtórne, powstające w wyniku utleniania miedzi zawartej w kruszcu, mogą tworzyć się zarówno w głębi ziemi - tam, gdzie mógł docierać tlen - jak i na hałdach na powierzchni już wytopionego materiału, jeśli pozostała w nim jakaś nawet śladowa ilość miedzi. W literaturze staropolskiej azuryt występował pod nazwą „lazur” lub „lazurium”, natomiast malachit określany był jako 
„saftgrün”, „miedzianka” albo „zielenica”. Pod nazwami „viridis”1, „grispan” bądź „zielona farba” kryć się może natomiast grynszpan, czyli grupa związków (octanów miedzi) powstających w wyniku korozji miedzi pod wpływem octu, zsiadłego mleka, moczu lub osadu winiarskiego ${ }^{2}$. Ten ostatni pigment, niemający żadnego zastosowania przemysłowego, był prawdopodobnie produkowany przy hucie lub kopalni wyłącznie z zamiarem sprzedaży do celów artystycznych. W historycznej literaturze francuskiej pojawia się również termin cendre bleue (niebieski popiół) na określenie słabej jakości błękitu miedzianego, stosowanego w malarstwie temperowym, pochodzącego z polskich kopaln ${ }^{3}$. Wprawdzie Watin mówi o kamieniu, z którego ucierany miał być „niebieski popiół”, jednak wydaje się, że termin ten mógł się odnosić raczej do mało stabilnego błękitnego węglanu miedzi produkowanego drogą syntezy chemicznej, choć nie można całkowicie wykluczyć słabo wykrystalizowanego minerału ${ }^{4}$. Nazewnictwo stosowane w materiałach archiwalnych nie jest konsekwentne i wymaga indywidualnej interpretacji. Handel pigmentami stanowił promil działalności świętokrzyskich kopalń i odbywał się na marginesie rozwoju przemysłu metalurgicznego ${ }^{5}$. $Z$ tutejszej miedzi wytwarzano m.in. blachę miedzianą używaną do krycia dachów 6 .

1 „W handlu pod nazwiskiem viride aeris znany,” por. Samuel Bogumił Linde, Słownik języka polskiego, t. 1, cz. 2 (Warszawa: Drukarnia XX. Piiarów, 1808), 790. „Wystawując blachy miedziane na długie działanie octu lub pary octowey, powierzchnia ich okrywa się niebiesko-zielonym proszkiem znaiomym w handlu pod nazwiskiem grynszpanu (viride aeris)," por. Jędrzej Śniadecki, Początki chemii dla użycia słuchaczów akademickich ułożone, t. 2 (Wilno: Józef Zawadzki, 1807), 217.

2 Nicholas Eastaugh et al., The Pigment Compendium. A Dictionary and Optical Microscopy of Historical Pigments (Oxford: Butterworth-Heinemann, 2008), 391.

3 Eastaugh et al., The Pigment Compendium, 59. Jean-Félix Watin, L'art du peintre, doreur et vernisseur, ouvrage utile aux artistes et aux amateurs qui veulent entreprendre de peindre, dorer et vernir toutes sortes de sujets en bâtimens, meubles, bijoux, equipages, etc. ... (Paris: Grangé, Durand, Watin, 1773), 31: „Cendre bleue: on donne ce nom à une pierre bleue \& tendre, grainelée, presque réduite en poudre, qu'on retrouve dans des mines de cuivre, en Pologne...” W tekście nie wskazano, z których kopalń pigment ten mógł pochodzić. Należy zauważyć, że w XVIII w. były również eksploatowane kopalnie w Tatrach, zob. Danuta Molenda, „Eksploatacja rud miedzi i handel miedzią w Polsce w późnym średniowieczu i w początkach nowożytności (do 1795 r.)," Przegląd Historyczny 80, z. 4 (1989): 801-802.

4 Eastaugh et al., The Pigment Compendium, 59.

5 Molenda, „Eksploatacja,” 801.

6 Paweł Król i Jan Urban, „Kopalnie w Miedzianej Górze i w Ławęcznej oraz ochrona ich pozostałości," Rocznik Świętokrzyski. Seria B - Nauki Przyrodnicze 29 (2003): 7. 


\section{Miedzianka}

Na terenie starostwa chęcińskiego wchodzącego w skład dawnego województwa sandomierskiego znajdował się pierwszy w Górach Świętokrzyskich, znany już w średniowieczu, ważny ośrodek wydobycia i obróbki miedzi ${ }^{7}$. Pod Chęcinami, w obrębie miejskiej wsi Polikno (obecnie Polichno) wznosi się góra Miedzianka - słynna z wydobywanych tam dobrej jakości kruszców8 W XV i XVI stuleciu wokół miasta trwała intensywna eksploatacja złóż kruszcowych - potwierdzają to wzmianki w opisach geograficznych ówczesnych kronikarzy9. Między innymi w powstałym około lat 1455-1480 manuskrypcie „Chorographia Regni Poloniae” Jan Długosz wymieniał występujący wokół Chęcin azuryt: „Chęciny, góra [...] obfita tak w swoich zboczach, jak i w okolicach w lazurowy kamień i miedź" ${ }^{10}$. Marcin Kromer w wydanym w 1577 roku kompendium geograficznym Polonia pokrótce opisał miejscowe złoża: „Pod Chęcinami wiele jest miedzi, lazuru i ołowiu”"11. Rok później podobną uwagę

7 Danuta Molenda, „Górnictwo chęcińskie w XVI i XVII wieku i jego związki z górnictwem śląsko-krakowskim,” w Dzieje i technika świętokrzyskiego górnictwa i hutnictwa kruszcowego. Materiały z sesji naukowej odbytej z okazji jubileuszu IX wieków Kielc 16 listopada 1970 roku, red. Zbigniew Kowalczewski (Warszawa: Wydawnictwa Geologiczne, 1972), 108-109; Zbigniew Kowalczewski, „O surowcach mineralnych i rozwoju górnictwa w okolicach Chęcin,” w VII wieków Chęcin. Materiały sesji naukowej 24 V 1975, red. Zenon Guldon (Kielce: Wyższa Szkoła Pedagogiczna w Kielcach / Urząd Miasta i Gminy w Chęcinach, 1976), 94-95; Hubert Mazur, „Źródła do dziejów Chęcin w zasobie Archiwum Państwowego w Kielcach,” Między Wisłą a Pilicą 12 (2011): 4.

8 W XVI w. trwał spór o Polikno między miastem Chęciny i starostwem. Ostatecznie rozstrzygnął go Zygmunt August w 1559 r. Po śmierci podstarościego chęcińskiego i gwarka olkuskiego Marcjana Przyłęckiego i jego żony Zofii Polikno miało przypaść miastu. Franciszek Maksymilian Sobieszczański, „Wycieczka archeologiczna w niektóre strony guberni radomskiej odbyta w miesiącu wrześniu r. z. (dokończenie)," Biblioteka Warszawska. Pismo poświęcone naukom, sztukom i przemysłowi 2 (1852): 28-68.

9 Relacje te zebrał jeszcze w XVIII w. Józef Osiński, Opisanie polskich żelaza fabryk, $w$ którym świadectwa Historyków wzmiankujących miejsca Minerałów przytoczone; Przywileie nadane szukającym Kruszców w całości umieszczone; początek wyrabiania u nas żelaza odkryty; Rudy Kraiowey czterdzieści ośm gatunków w kolorach właściwych wydane i w szczególności wyłożone; Piece i Dymarki w całym Krolestwie znayduiące się wyliczone; z żelaza Kraiowy zysk okazany; Słownik Kuźniacki, oprócz wyrazów Technicznych, wiele wiadomości zawierający przydany (Warszawa: Druk. IKM i Rzeczypospolitey u XX. Scholarum Piarum, 1782), 5-7.

10 Jan Długosz, Roczniki, czyli Kroniki sławnego Królestwa Polskiego, ks. 1, ks. 2 do 1038, red. Jan Dąbrowski, tłum. Stanisław Gawęda, przedmowa Wanda Semkowicz-Zarembina (Warszawa: Wydawnictwo Naukowe PWN, 2009²), 159; por. Wacława Szelińska, „Chorographia Regni Poloniae" Jana Długosza (Kraków: Wydawnictwo Naukowe Wyższej Szkoły Pedagogicznej w Krakowie, 1980), 32.

11 Martini Cromeri Polonia sive De situ, populis, moribus, magistratibus et republica regni Polonici libri duo, 1578, wyd. Wiktor Czermak (Kraków: Akademia Umiejętności, 1901), 24, tłum. za: 
zamieścił Aleksander Gwagnin w swoim dziele Sarmatia: „Chęciny [...] słynne kopalniami lazuru, gdzie i srebro znajduje się"12.

Zachowało się stosunkowo dużo przekazów z XV-XVIII wieku informujących nie tylko o pozyskiwaniu w tym miejscu rud metali - w tym miedzi - oraz minerałów azurytu i malachitu, ale też o handlu tymi pigmentami. Do najważniejszych świadectw źródłowych należą lustracje starostwa chęcińskiego, zawierające m.in. opisy najstarszych przywilejów wystawionych dla mieszczan chęcińskich. W lustracji z lat 1602-1603 wymieniony został przywilej Kazimierza Jagiellończyka z 1487 roku na budowę huty do oczyszczania rudy złota („ad frixensis purgandamque aurem”) przy sadzawce pod Poliknem, na miejscu jeszcze starszej budowli ${ }^{13}$. Najdawniejsza wzmianka o kopalniach chęcińskich pochodzi z 1494 roku, gdy Jan Olbracht postanowił, by w sporach górniczych żupnik chęciński sądził według praw olkuskich ${ }^{14}$.

Górnicy mieli prawo handlowania wydobytym kruszcem i mogli go sprzedać dowolnemu kupcowi po opłaceniu olbory (dziesięciny) królowi w wysokości 10,3\% i żupnikowi w wysokości 6,1\% wartości uzyskanej rudy ${ }^{15}$. Przywilej ten unieważniały jedynie potrzeby królewskie: władca dysponował wtedy bowiem prawem pierwokupu i nakazywał skup kruszców do zamku chęcińskiego. Z prawa tego skorzystali m.in. Zygmunt I Stary w 1512 roku oraz Zygmunt III Waza w 1621 roku, jak wynika ze źródeł przytoczonych poniżej ${ }^{16}$.

Wiele dokumentów dotyczących handlu pigmentami pochodzi z pierwszej połowy XVI wieku, gdy trwała renesansowa przebudowa zamku królewskiego na Wawelu. Na przykład w kwietniu 1508 roku kupiono prawie

Julian Ursyn Niemcewicz, Podróże historyczne po ziemiach polskich od 1811 do 1828 roku odbyte (Paryż: Księgarnia A. Francka / Petersburg: Księgarnia B. M. Wolffa, 1858), 24.

12 Aleksander Gwagnin, Sarmatiae Europeae descriptio, quae Regnum Poloniae, Lituaniam, Samogitiam [...] partem complecitur (Kraków: Maciej Wierzbięta, [po 20 VI 1578]), fol. 59 (tłum. Michał Witkowski); por. Hieronim Łopaciński, „Wiadomości o marmurach w Polsce z rękopisów oraz dzieł dawnych i nowszych," Sprawozdania Komisyi do Badania Historyi Sztuki $w$ Polsce 7, z. 1-2 (1902): 591.

13 Archiwum Główne Akt Dawnych w Warszawie (dalej: AGAD), Metryka Koronna, Lustracje, sygn. 19, fol. 148v; por. Molenda, „Górnictwo,” 117, przyp. 7.

14 Hieronim Hilary Łabęcki, Górnictwo w Polsce: opis kopalnictwa i hutnictwa polskiego pod względem technicznym, historyczno-statystycznym i prawnym, t. 1 (Warszawa: Drukarnia Juljana Kaczanowskiego, 1841), 293-294. Por. Molenda, „Górnictwo,” 109, 117 i przyp. 8.

15 Marian Paulewicz, Chęcińskie górnictwo kruszcowe od XIV do połowy XVII wieku (Kielce: Kieleckie Towarzystwo Naukowe, 1992), 40. W 2. poł. XVI w. powszechną praktyką finansowania wydobycia były pożyczki udzielane przez kupców, spłacane następnie przez górników uzyskanym kruszcem z dodatkowym procentem, zob. Paulewicz, Chęcińskie górnictwo, 111 i przyp. 18.

16 Molenda, „Górnictwo,” 111 i przyp. 18. 
dwadzieścia sześć funtów lazuru (azurytu, „lazurium”), płacąc od 8 do 40 groszy za funt, zapewne w zależności od jakości pigmentu, do wykorzystania przy zdobieniu zamku ${ }^{17}$. Inwentarz starostwa chęcińskiego wymienia w tym samym roku wieś miejską Polikno, z której dziesięcina od wydobycia lazuru płacona była do zamku w Chęcinach ${ }^{18}$.

Jak podaje Jan Ptaśnik, chęciński azuryt mógł być w tym czasie - na przełomie XV i XVI wieku - eksportowany nawet do Brugii, badacz odnalazł bowiem wzmiankę o działającym w tym mieście sprzedawcy tego pigmentu Mikołaju Polaku (Claeys Polains) ${ }^{19}$. W maju 1508 roku zawarto umowę z malarzem Michałem Lanczem z Kitzingen na wymalowanie komnat zamkowych na Wawelu ${ }^{20}$. Pigmenty zielone („viridis”) i niebieskie („lazuri”) dostarczył wówczas Leonard z Chęcin ${ }^{21}$. Pigmenty te kupowano w kilku różnych gatunkach, o czym świadczą znacznie zróżnicowane ceny, wynoszące od 3 do 7,5 grosza za funt grynszpanu lub malachitu (zakupiono 18,5 funta) i od 10 do 36 groszy za funt azurytu, którego kupiono znaczne ilości (60 funtów i 24 łuty $)^{22}$. W styczniu i marcu kolejnego roku u Leonarda z Chęcin te same pigmenty nabyto jeszcze dwukrotnie. Zakupiono najpierw pięćdziesiąt i pół funta grynszpanu po 3 grosze za funt oraz czterdzieści trzy funty lazuru (azurytu) wartego od 12 do 36 groszy za funt, następnie czternaście funtów grynszpanu lub malachitu po 7,5 grosza za funt, a także ponad siedemnaście funtów lazuru różnego gatunku w cenie od 10 do 36 groszy za funt ${ }^{23}$.

17 Teka Grona Konserwatorów Galicyi Zachodniej, t. 5 Wawel, t. 2 Materyały archiwalne do budowy zamku, oprac. Adam Chmiel (Kraków: Drukarnia Uniwersytetu Jagiellońskiego pod zarządem J. Filipowskiego, 1913), 13; por. Marcin Fabiański, Zamek króla Zygmunta I na Wawelu. Architektura - dekoracja architektoniczna - funkcje (Kraków: Zamek Królewski na Wawelu Państwowe Zbiory Sztuki, 2017), 50 i przyp. 126.

18 AGAD, Archiwum Skarbu Koronnego, sygn. 43, s. 3.

19 Jan Ptaśnik, „Lazur polski z Chęcin w XV w.,” Prace Komisji Historii Sztuki 1, z. 2 (1919): XXVIII.

20 Fabiański, Zamek, 49.

${ }^{21}$ Rachunki wielkorządowe Jana Bonera 1558, oprac. Józef Garbacik (Źródła do Dziejów Wawelu 7) (Kraków: Nakładem Ministerstwa Kultury i Sztuki, 1974), 160: „Item pro octo libris lazuri Chanczinensis per mc. 1 gr 12 et 17 coloris virdis quolibet per gr 10-mc. 13, gr 31.”

22 Klemens Bąkowski, Zamek krakowski (Kraków: Spółka Wydawnicza Polska, 1913), 82. Po inne pigmenty malarz musiał wybrać się do Wrocławia; por. Fabiański, Zamek, 50 i przyp. 126. W 1530 r. Hans Dürer zamiast lazuru używał znacznie tańszego indygo (4 uncje /ok. 104 g/ za 30 gr), zob. Rachunki do budowy zamku krakowskiego 1530, oprac. Marek Ferenc (Źródła do Dziejów Wawelu 18) (Kraków: Zamek Królewski na Wawelu - Państwowe Zbiory Sztuki, 2006), 90.

23 Teka Grona Konserwatorów, 17; por. Fabiański, Zamek, 50 i przyp. 126. 
W 1510 i 1511 roku w celu wykonania dekoracji przypuszczalnie wielkiej sali („aulam”) królewskiej nowego skrzydła północnego kupiono grynszpan („grispan”, 48 funtów po 14 gr) i azuryt (24 funty po 20 gr i 4 funty dobrego lazuru po 36 gr za funt) ${ }^{24}$. W lipcu 1512 roku król Zygmunt I Stary w liście do starosty chęcińskiego Stanisława Szafrańca azuryt wydobywany koło Chęcin zarezerwował dla siebie i na potrzeby królewskie, nakazując jednocześnie, by nikt inny pod karą go nie wydobywa ${ }^{25}$.

W 1525 roku na sejmie piotrkowskim Zygmunt I wydał podżupkowi („vice-zuppario”) i gwarkom („cultoribus montium”) chęcińskim przywilej górniczy (ordynację królewską), w którym zarządzał, by gwarkowie nie sprzedawali miedzi, ołowiu i lazuru bez wiedzy podżupka ${ }^{26}$. W tym samym roku malarz krakowski Stanisław Swach był winien Dorocie Dzierzynie z Chęcin pewną sumę za wzięty od niej lazur ${ }^{27}$.

W czerwcu 1529 roku kupiono dziesięć funtów zielonego pigmentu („viridis”), prawdopodobnie grynszpanu, po 10 groszy za funt, do malowania okiennic („fenestralia”) w Kurzej Nodze na Wawelu, gdzie działał wówczas warsztat Hansa Dürera ${ }^{28}$. W październiku pracujący z Dürerem malarz

24 Rachunki podskarbiego Andrzeja Kościeleckiego z lat 1510-1511, oprac. Anna Wajs i Hubert Wajs (Źródła do Dziejów Wawelu 15) (Kraków: Zamek Królewski na Wawelu, 1997), 54. Por. Fabiański, Zamek, 50 i przyp. 127; należy zauważyć, że Fabiański słowa „bonum lazurum” interpretuje jako określenie ultramaryny. W 1520 r. malarz Jan Goraj wraz z Janem iluminatorem pobierali lazur chęciński, co stanowiło przedmiot rozprawy sądowej z Jadwigą Słupkową z Chęcin w kwietniu tego roku. Wypisy źródłowe do dziejów Wawelu z archiwaliów kapitulnych i kurialnych krakowskich 1516-1525, oprac. Bolesław Przybyszewski (Źródła do Dziejów Wawelu 5) (Kraków: Ministerstwo Kultury i Sztuki, 1970): XX, 89; Jerzy Gadomski, Gotyckie malarstwo tablicowe Małopolski, t. 3 1500-1540 (Warszawa: Państwowe Wydawnictwo Naukowe, 1995), 46.

25 Biblioteka Książąt Czartoryskich, Oddział Muzeum Narodowego w Krakowie, cod. nr 253: 318, List króla Zygmunta z 20 lub 21 VII 1512: „[...] colores ipsius lazuri pro nobis servarentur,” za: Stanisław Kutrzeba, „Wypowiedź w sprawie listów Zygmunta I do Stanisława Szafrańca w sprawie chęcińskiego lazuru," Sprawozdania Komisyi do Badania Historyi Sztuki $w$ Polsce 7, z. 3 (1903): CCXXVIII-CCXXIX (posiedzenie z dn. 13 XII 1900, na którym S. Kutrzeba omawiał ten list i był zdania, że świadczy on o przybliżonej dacie rozpoczęcia wydobycia azurytu w okolicach Chęcin).

26 Łabęcki, Górnictwo, t. 1, 294: „Ordinatio cultoribus montium oppidi Chanczyny a rege praescripta." Przyczyną był brak wymienionych towarów na krajowym rynku.

27 Edward Rastawiecki, Słownik malarzów polskich tudzież obcych $w$ Polsce osiadłych lub czasowo $w$ niéj przebywających, t. 2 (Warszawa: Nakładem autora w drukarni S. Orgelbranda, 1851), 250; por. Archiwum Narodowe w Krakowie, Akta miasta Krakowa, sygn. 432, s. 1036: „Stanislaus Swyach pictor recognovit se teneri veri justi et p[ro]prii debiti [...] Dorote Dzazyna [Dzierzyna] de Chaczyny [z Chęcin] pro lazurio ab e[a] empto."

28 Teka Grona Konserwatorów, 125. 
Bernard Golczlor (Golthschlor) kupił też oprócz innych farb dwa funty saftgrünu (zapewne malachitu) po 12 groszy za funt. Tenże malarz na potrzeby Hansa Dürera do malowania Kurzej Nogi kupił 7 funtów „dobrego lazuru” po 32 grosze oraz dwa funty lazuru chęcińskiego po 20 groszy i ponownie siedem i pół funta lazuru w dobrym gatunku po 30 groszy za funt ${ }^{29}$. Z kolei w listopadzie Dürer odebrał od Marcina płatnerza sześć funtów lazuru zwykłego po 12 groszy za funt do malowania „pavimenti superioris” w Kurzej Nodze ${ }^{30}$. Malarz krakowski Stanisław Szczerba (Sczirba) wykorzystał w grudniu tego roku zielony pigment do pomalowania okuć bramy zamkowej ${ }^{31}$. O prowadzonym w XVI wieku przez mieszczan chęcińskich handlu pigmentami świadczy też zobowiązanie dłużne Jana Kosiora, malarza bocheńskiego, wystawione w 1530 roku dla malarza Jana z Chęcin za kupno farb („coloribus”) ${ }^{32}$.

Początkowo wydobycie niektórych minerałów było zawarowane dla króla i jego potrzeb. W 1550 roku mieszczanie chęcińscy otrzymali od króla Zygmunta Augusta prawo gwareckie nadane według prawa olkuskiego na swobodne wydobywanie kruszców, w tym m.in. srebra, miedzi, żelaza, lazuru i cynobru, również na starych wyrobiskach, a ponadto na stawianie hut i wolny wyrąb drzew w lasach królewskich na wszelkie potrzeby górnicze ${ }^{33}$. Przywilej ten okazywano aż do drugiej połowy XVIII wieku, choć w ostatniej zachowanej lustracji z 1765 roku mieszczanie skarżyli się, że w 1621 roku odebrano im swobody górnicze, a użytek gór kruszcowych ponownie zarezerwowano wyłącznie dla dworu ${ }^{34}$.

W latach 1552-1562 duże ilości miedzi wywożono z Korony na Litwę, do Wilna. W 1555 roku zapisano, że pochodziła ona z zakupu w Chęcinach - od Klemensa Konratowicza oraz Grzegorza Oziswiny ${ }^{35}$. W połowie stycznia tego samego roku w związku z pracami przy dekoracji zamku wielkoksiążęcego

29 Teka Grona Konserwatorów, 126.

30 Teka Grona Konserwatorów, 126.

31 Teka Grona Konserwatorów, 126.

32 Wypisy źródłowe do dziejów Wawelu $z$ archiwaliów kapitulnych i kurialnych krakowskich 1530-1533, oprac. Bolesław Przybyszewski (Zródła do Dziejów Wawelu 11) (Kraków: Ministerstwo Kultury i Sztuki, 1986), 63, za: Archiwum Kurii Metropolitalnej w Krakowie, Acta Officialia Cracoviensia, 47: 1080. Przybyszewski jest zdania, że malarze krakowscy zaopatrywali się w lazur u malarzy chęcińskich od czasów średniowiecza, zob. Wypisy źródłowe [...] 1530-1533, 63.

33 AGAD, Metryka Koronna, Lustracje, sygn. 29, k. 180r; Łabęcki, Górnictwo, t. 1, 294.

34 AGAD, Metryka Koronna, Lustracje, sygn. 36, k. 98r.

35 Rachunki dworu królewskiego 1544-1567, oprac. Adam Chmiel (Źródła do Historyi Sztuki i Cywilizacyi w Polsce) (Kraków: Akademia Umiejętności, 1911), 12. 
w Wilnie wysłano na Litwę za pośrednictwem Grzegorza Oziswiny pigmenty do farb („colores”) pochodzące z olbory chęcińskiej (dziesięciny górniczej, czyli dochodów skarbu królewskiego), w tym dwa gatunki lazuru (dobrego i zwykłego) o łącznej wadze dwudziestu czterech funtów i sześciu uncji, dwa gatunki pigmentu zielonego, zapewne malachitu (grubszego „gravioris” i drobniejszego „levioris”), razem ważące 8 funtów 48 uncji, oraz „vasculo quercino ad eodem colores”, czyli naczynie dębowe do tych pigmentów za 5 florenów ${ }^{36}$. Malarze byli tam już od marca 1554 roku, wtedy również wydano znaczną sumę m.in. na zakup pigmentów („pro coemendis coloribus”) ${ }^{37}$.

Górę Miedziankę jako miejsce wydobycia pigmentów zielonych i niebieskich wskazuje dokładnie lustracja województwa sandomierskiego z lat 1564-1565: „Góra Miedzianka za Polyknem. - Ta góra te skarby w sobie ma: naprzód kruszec miedziany, lazur modry i zielenicę albo zieloną farbę"38. W lustracji starostwa chęcińskiego z 1569 roku ponownie opisana jest Miedzianka: „Czwarta góra za wioską miejską Poliknem, którą zowią Miedzianka, i tamże huty miejskie. W tej górze kruszec miedziany bardzo dobry i srebra niemało. Lazur przy nim barzo kosztowny i zielenica barzo cudna. $Z$ tej góry za innych czasów bardzo wiele skarbów wychodziło i dziś jest ich wiele; ale trzeba robić jedno by trzeba nakładu wielkiego" 39 . Z opisu wynika, że wydobycie kruszców w Miedziance, w tym malachitu i azurytu, w drugiej połowie XVI wieku stawało się coraz bardziej kosztowne. W 1571 roku Zygmunt August wydał staroście chęcińskiemu Stanisławowi Dębińskiemu nowe pozwolenie na poszukiwanie rud kruszcowych wokół Chęcin i w całym województwie sandomierskim, co zdaniem Hieronima Hilarego Łabęckiego świadczyło pośrednio o spadku dochodów, spowodowanym stopniowym wyczerpywaniem się łatwo dostępnych złóż ${ }^{40}$. W latach 1602-1603 wydobycie w Miedziance musiało być nadal prowadzone, jak informuje o tym tekst kolejnej lustracji: „czynszu nie płacą, jeno robią w Górach na Miedziance” ${ }^{\text {. W }} 1612$ roku

36 Rachunki dworu, 60.

37 Rachunki dworu, 49.

38 Paulewicz, Chęcińskie górnictwo, 99, za: Lustracje dóbr królewskich XVI-XVIII wieku, [t. 1] Małopolska, [cz. 1] Lustracja województwa sandomierskiego: 1564-1565, oprac. Władysław Ochmański (Wrocław-Warszawa-Kraków: Państwowe Wydawnictwo Naukowe, 1963), 285-286.

39 AGAD, Metryka Koronna, Lustracje, sygn. 29, fol. 185v. Tekst lustracji wymienia jeszcze inne świadectwa górniczej przeszłości starostwa: Starą Hutę koło Radoszyc oraz staw przy opuszczonej Rudzie, o zakwaszonej wodzie, niezdatnej do hodowli ryb, zob. fol. 211v i 214r.

40 Łabęcki, Górnictwo, t. 1, 295.

41 AGAD, Metryka Koronna, Lustracje, sygn. 19, fol. 156v. 
o srebrze i lazurze chęcińskim wspomniał nawet w swoim kompendium geograficznym flamandzki filozof, matematyk i geograf Petrus Bertius (1565$1629)^{42}$.

Załamanie eksploatacji złóż w Miedziance nastąpiło około 1615 roku. Lustratorzy w tym roku zapisali, że „w tej górze kruszec miedziany bardzo dobry i srebra ma niemało, przy którym po części lazuru i zielenice. Mieli tam z dawna mieszczanie chęcińscy i inszy gwarkowie szyby swe, ale ich odbiegli i sztołę bito wielkim sumptem Króla Jegomości, która się zawaliła, i żadnego stamtąd pożytku nie masz" ${ }^{33}$. W tym samym mniej więcej czasie wzmianka o kopalniach lazuru i srebra w Chęcinach znalazła się jednak w atlasie Gerarda Mercatora wydanym w Dordrechcie w 1610 roku $^{44}$.

Dzięki szczątkowo zachowanym za czasów Łabęckiego księgom żupniczym chęcińskim wiadomo, że w XVII wieku (na pewno w latach 1617-1659) w okolicach Chęcin, m.in. w Miedziance (pomimo problemów z odwodnieniem kopalni), funkcjonowało górnictwo kruszcowe, choć na ograniczoną skalę ${ }^{45}$. Eksploatowano przede wszystkim złoża rud ołowiu, ale też miedzi, o czym świadczą licencje wydawane na poszukiwania i wydobycie udzielane w tym czasie osobom ze wszystkich stanów społecznych. Dłuższą przerwę w kopaniu rud miedzi w rejonie Chęcin spowodował dopiero najazd szwedzki z lat 1655-1660. Mimo to jeszcze w drugiej połowie XVII wieku starosta chęciński i wojewoda sandomierski Stefan Bidziński (1630-1704) kazał sporządzić „z lazuru” („tabula lazuli”) znalezionego w okolicy stolik ofiarowany papieżowi Innocentemu $\mathrm{XI}^{46}$.

42 Petri Bertii Geographischer eyn oder zusammengezogener Tabeln Fünff uterschiedliche Bücher (Franckfurt: Heinrich Lorentzen, Matth. Becker, 1612), 533: „Beneben der stadt Checiny auf dem ebenen Feldt / welche von wegen ihrer Silber unnd Lasur Gruben gnugsamb ist berühmt".

43 AGAD, Metryka Koronna, Lustracje, sygn. 69, fol. 213r.

44 Atlas minor Gerardi Mercatoris à I. Hondio plurimi æneis tabulis auctus atque illustratus (Dordrecht: Excudebat Adrianus Bottius, 1610), 472: „Checiny in loco plano fodinis Lazuri clara...”

45 Łabęcki, Górnictwo, t. 1, 296-297. Rejestr licencji górniczych z lat 1617-1659 znajdował się wówczas w odpisie w Archiwum Wydziału Górniczego Komisji Rządowej Przychodów i Skarbu w Warszawie. Zachowane w późniejszych odpisach dwa inne fragmenty chęcińskich ksiąg żupniczych z lat 1646-1648 i 1656-1659 przechowywane są w Archiwum Państwowym w Kielcach, Komisja Województwa Krakowskiego, sygn. 86.

46 Zob. Auctuarium historiae naturalis curiosae Regni Poloniae, Magni Ducatus Lithuaniae, annexarumque provinciarum, per P. Gabrielem Rzaczynski Soc. Jesu. concinnatum. Opus pothumum cum permissu superiorum (Gdańsk: [s.n.], 1745), 65; „Analyse de l'histoire naturelle de Pologne du P. Gab. Rzączyński," w Jean-Baptiste Dubois, Essai sur l'histoire littéraire de Pologne (Berlin: G. I. Decker imprimeur du roi, 1778), 474. 


\section{Miedziana Góra}

Drugim obszarem górnictwa kruszcowego w Górach Świętokrzyskich były okolice Kielc. Dobra biskupów krakowskich obejmowały m.in. leżącą na gruntach wsi Kostomłoty Miedzianą Górę i Karczówkę, w obydwu tych miejscach wydobywano rudę miedzianą ${ }^{47}$. Według Hieronima Łabęckiego początki górnictwa miedzi sięgały w tym rejonie XV wieku, na Miedzianej Górze podjęli wtedy pracę górnicy sprowadzeni z Olkusza. Znajdowano tam malachit i lazur, a wydobycie rozwinęło się najbardziej pod koniec XVI stulecia ${ }^{48}$.

Okolice Kielc należały do dóbr biskupów krakowskich od przełomu XI i XII wieku ${ }^{49}$. Miejscowości i folwarki na tym terenie tworzyły administracyjną jednostkę gospodarczą biskupstwa zwaną kluczem kieleckim. Jeszcze w 1220 roku książę Leszek Biały nadał biskupstwu krakowskiemu dziesięciny $\mathrm{z}$ dochodów kopalń różnych metali wydobywanych wówczas w Polsce, w tym kopalni miedzi ${ }^{50}$. Biskupi krakowscy rozwijali tę gałąź gospodarki w kolejnych stuleciach, wydając również zezwolenia na poszukiwanie i wydobywanie rud metali $^{51}$.

Nowe złoża rudy miedzi w Miedzianej Górze odkrył Jan Niedźwiedź z kuźnicy Jasiów nad Bobrzą około 1590-1592 roku i wkrótce potem nad złożem powstała osada górnicza o tej nazwie ${ }^{52}$. Kopalnia w Miedzianej Górze dostarczała urobek do huty w Białogonie. Wydobycie znacznych ilości miedzi poświadczone jest w materiałach archiwalnych od końca XVI do połowy XVII wieku.

Biskup Jerzy Radziwiłł podarował królowi Zygmuntowi III Wazie miedź z kopalni na pokrycie spalonych w 1595 roku dachów zamku królewskiego na Wawelu ${ }^{53}$. Nakazał również przekazywać co kwartał cetnar miedzi z biskupich kopalń kieleckich proboszczowi erygowanego przez siebie w 1599 roku

47 Łabęcki, Górnictwo, t. 1, 300. Król i Urban, „Kopalnie,” 6-7; Paweł Król i Jan Urban, Geologiczne i historyczne dziedzictwo górnictwa miedzianogórskiego (Kielce: Agencja „JP” s.c., 2012), 3, 24.

48 Łabęcki, Górnictwo, t. 1, 301.

49 Bolesław Stanisław Kumor, Dzieje archidiecezji krakowskiej do roku 1795, t. 1, red. Jacek Urban (Kraków: Wydawnictwo św. Stanisława BM Archidiecezji Krakowskiej, 1998), 186.

50 Kumor, Dzieje, 180, 184.

51 Kumor, Dzieje, 194-195.

52 Heliodor Kmieć, Dzieje techniki zbrojeniowej nad rzeka Bobrza i w jej okolicach od XVI do XIX wieku (Kielce: Regionalny Ośrodek Studiów i Ochrony Środowiska Kulturowego, 2000), 43.

53 Paweł Piasecki, Chronica gestorum in Europa singularium (Kraków: In Officina Typographica Francisci Cæsarii, 1645), 151: „Regi tantum cupri dederat, quantum suffecerit tectis restituendis illo incendio absumptis”; zob. Osiński, Opisanie, 6; Niemcewicz, Podróże, 21; Łabęcki, Górnictwo, t. 1, 301. 
kościoła pw. św. Stanisława w Tumlinie ${ }^{54}$. Parafia ta została założona ze względu na liczne osadnictwo górników i hutników pracujących w szybach miedzianogórskich.

W 1595 roku lipski prawnik i kupiec Georg Winter (ok. 1551-1618) założył wraz z krakowskimi mieszczanami spółkę górniczą i uzyskał przywilej na eksploatację górniczo-hutniczą części złóż miedzi w kopalniach Miedzianej Góry przez piętnaście lat ${ }^{55}$. Spółka ta dysponowała dwudziestoma działkami górniczymi na terenie osady Miedziana Góra i wyłącznym prawem wytopu miedzi w hucie w Białogonie, którą Winter wydzierżawił od kardynała Jerzego Radziwiłła lub może wybudował w latach 1595-1597 - w każdym razie według przywileju biskupa Bernarda Maciejowskiego posiadał ją w roku $1601^{56}$. Winter od 1587 roku był zięciem Heinricha Cramera von Claußbruch (1515-1599), pochodzącego z Arras najbogatszego saskiego kupca, prowadzącego handel hurtowy metalami, tkaninami i klejnotami w całej Europie Północnej. Pełnił on funkcję pośrednika między ośrodkami handlu środkowoeuropejskiego, takimi jak Kraków, Poznań i Gdańsk, a Europą Zachodnią ${ }^{57}$. Cramer na dużą skalę handlował miedzią i srebrem, miał również udziały w kopalniach, m.in. w górach Harzu i Rudawach, zarówno w Saksonii, jak i w Królestwie Czech. Winter, który współprowadził kantor Cramera od czasu ślubu z jego córką, w 1593 roku przyjął prawo miejskie Lipska, a połowie lat dziewięćdziesiątych XVI wieku całkowicie przejął kierowanie przedsiębiorstwem ${ }^{58}$. Działalność Wintera w górnictwie okolic Chęcin zakończyła się w 1610 roku, prawdopodobnie

54 Niemcewicz, Podróże, 21; por. Łabęcki, Górnictwo, t. 1, 301: „de mineris et officinis nostris Kielcensibus unum centenarium aeris percussi et facti, [...] submittimus”.

55 Kmieć, Dzieje, 43. Związki kupiectwa chęcińskiego z Saksonią znane są od 1540 r. Kupcy z Zwickau winni byli wówczas Pawłowi Dzierzy znaczną sumę 4 tys. florenów.

56 Kmieć, Dzieje, 44.

57 Ernst Kroker, „Heinrich Cramer von Claußbruch, ein Leipziger Handelsherr des 16. Jahrhunderts," w Quellen zur Geschichte Leipzigs, t. 2, oprac. Gustav Wustmann (Leipzig: Duncker \& Humblot, 1895), 355-386; Herbert Helbig, „Cramer v. Claußbruch,” w Neue Deutsche Biographie, t. 3 Bürklein-Ditmar, red. Otto Graf zu Stolberg-Wernigerode et al. (Berlin: Duncker \& Humblot, 1957), 392-393. Winter ze swoim współpracownikiem Mosesem Polmannem odwiedzili m.in. kilka razy Kraków i Poznań w latach 90. XVI w., by zawrzeć transakcje handlowe z królem polskim na dostawę cennych kamieni szlachetnych i wyrobów ze złota, zob. Josef Reinhold, Polen / Litauen auf den Leipziger Messen des 18. Jahrhunderts (Weimar: H. Bohlaus, 1971), 8.

58 Manfred Unger, „Heinrich Cramer von Claußbruch,” w Sächsische Biografie, oprac. Institut für Sächsische Geschichte und Volkskunde e.V., online-Ausgabe, https://saebi.isgv.de/biografie/Heinrich_Cramer_von_Clau\%C3\%9Fbruch_(1515-1599), dostęp 2 maja 2021; Manfred Unger, „Georg Winter,” w Sächsische Biografie, oprac. Institut für Sächsische Geschichte und Volkskunde e.V., online-Ausgabe, https://saebi.isgv.de/biografie/Georg_Winter_um_15511618), dostęp 2 maja 2021 . 
na skutek uniemożliwiających wydobycie dopływów wody do szybów ${ }^{59}$. Odwodnienie wyrobisk przez budowę sztolni było celem nowej spółki, założonej w 1609 roku, która nie funkcjonowała jednak długo ${ }^{60}$.

Jeszcze w 1601 roku biskup krakowski Bernard Maciejowski ustanowił w Kielcach urząd górniczy, zwany urzędem górnym lub żupniczym. Urząd ten zarządzał sprawami górnictwa i hutnictwa w kluczach kieleckim i cisowskim biskupstwa krakowskiego. Powstanie urzędu górniczego świadczy o rozwoju wydobycia kruszców w tym okresie, jednak dochody z niego nie mogły być zadowalające, skoro w 1617 roku kolejny biskup krakowski, Marcin Szyszkowski, w ordynacji dla kopalń kieleckich nakazał gwarkom prowadzić poszukiwania rud metali kolorowych i wybudować kolejną sztolnię. Projekt ten także został wkrótce zarzucony i w 1626 roku biskup zezwolił na poszukiwanie kruszców pospólstwu w zamian za opłacanie olbory ${ }^{61}$. W drugiej połowie XVII wieku kopalnie miedzianogórskie dzierżawiła rodzina włoskich górników i hutników Gibbonich: Jan Gibboni, który otrzymał indygenat w 1654 roku, a następnie jego syn Jakub ${ }^{62}$.

Ponowny rozwój górnictwa miedzi w Miedzianej Górze nastąpił dopiero w drugiej połowie XVIII wieku na skutek badań Jana F. Carosiego, przeprowadzonych w opuszczonych kopalniach około 1780 roku $^{63}$. Wśród znalezionych i opisanych przez siebie kruszców Carosi wymienił „tęgi miedziany lazur”, czyli azuryt i różne formy malachitu ${ }^{64}$. Po 1784 roku wydobyciem na rzecz króla Stanisława Augusta Poniatowskiego kierował generał major w służbie polskiej, baron Antoni Aleksander Soldenhoff. Od 1787 roku kopalnię wraz z hutą w Niewachlowie król wydzierżawił oficjalnie od biskupa krakowskiego na czterdzieści lat, a w lipcu tego samego roku władca osobiście zwiedził zakład ${ }^{65}$. W czasie zarządu Soldenhoffa wydobyto malachit, którym po oszlifowaniu do formy płyt miano ozdobić pokoje króla w Warszawie ${ }^{66}$. Informacja ta, podana przez Franciszka Sobieszczańskiego, jest ostatnią wzmianką o wykorzystaniu w sztuce XVIII wieku pigmentów miedziowych ze złóż świętokrzyskich.

59 Król i Urban, „Kopalnie,” 10.

60 Król i Urban, „Kopalnie,” 10.

61 Król i Urban, „Kopalnie,” 10.

${ }^{62}$ Król i Urban, „Kopalnie,” 10; Król i Urban, Geologiczne, 25-26.

63 Król i Urban, Geologiczne, 27-30.

${ }^{64}$ Król i Urban, Geologiczne, 29, za: Jan F. Carosi, „List trzeci. Z Kielc, 15 Sierpnia,” w Jan F. Carosi, „Podróż przez niektóre prowincye polskie,” Magazyn Warszawski 2 (1784): 304-305.

65 Łabęcki, Górnictwo, t. 1, 303; Król i Urban, Geologiczne, 40.

66 Sobieszczański, Wycieczka, 207. 


\section{Podsumowanie}

W artykule zebrano rozproszone w literaturze z zakresu historii górnictwa, geologii i gospodarki informacje dotyczące handlu pigmentami miedziowymi z eksploatowanych od średniowiecza do XVIII wieku złóż świętokrzyskich. Uzupełniono je o wiadomości pozyskane ze źródeł. Przeprowadzone badania potwierdzają, że azuryt, malachit i prawdopodobnie grynszpan pochodzące z kopalń świętokrzyskich sprzedawano jako materiały artystyczne zarówno na rynku krajowym, jak i zagranicznym. Ze względu na brak ciągłości wydobycia nie były to stałe źródła pozyskiwania tych pigmentów, a co za tym idzie - nie mogły odgrywać istotnej gospodarczej roli w europejskim obrocie handlowym, choć były na tyle znane, że ich pochodzenie odnotowano kilkakrotnie w dokumentach oraz dziełach z zakresu geografii i traktatach artystycznych. Okres najbardziej intensywnego wydobycia pigmentów miedziowych przypadł w kopalniach Miedzianki na XVI wiek, w Miedzianej Górze na przełom XVI i XVII stulecia. W tym czasie azuryt i malachit ze złóż świętokrzyskich, a także grynszpan produkowany przy miejscowych hutach, posłużyły do dekoracji siedzib królewskich w Krakowie i Wilnie. Malachit i prawdopodobnie syntetyczny błękit miedziany, który również mógł pochodzić $\mathrm{z}$ regionalnych ośrodków, wykorzystywano natomiast w późniejszym okresie.

\section{Finansowanie}

Artykuł powstał w ramach realizacji projektu badawczego „Od złoża do palety malarza: pozyskiwanie i szlaki handlowe azurytu, malachitu i smalty na obecnym terytorium Polski" realizowanego ze środków Narodowego Centrum Nauki (nr 2015/19/N/ HS2/03503).

\section{Podziękowania}

Autorzy dziękują Muzeum Narodowemu w Kielcach i panu Pawłowi Królowi za udostępnienie archiwalnego zdjęcia góry Miedzianka (il. 1), panu Rafałowi Siudzie za aktualną fotografię tego miejsca (il. 2), fotografie (il. 3-4) i przekazanie okazów do badań (il. 6-7) oraz pani Ilonie Sekudewicz za udostępnienie zdjęcia okazu (il. 5). 


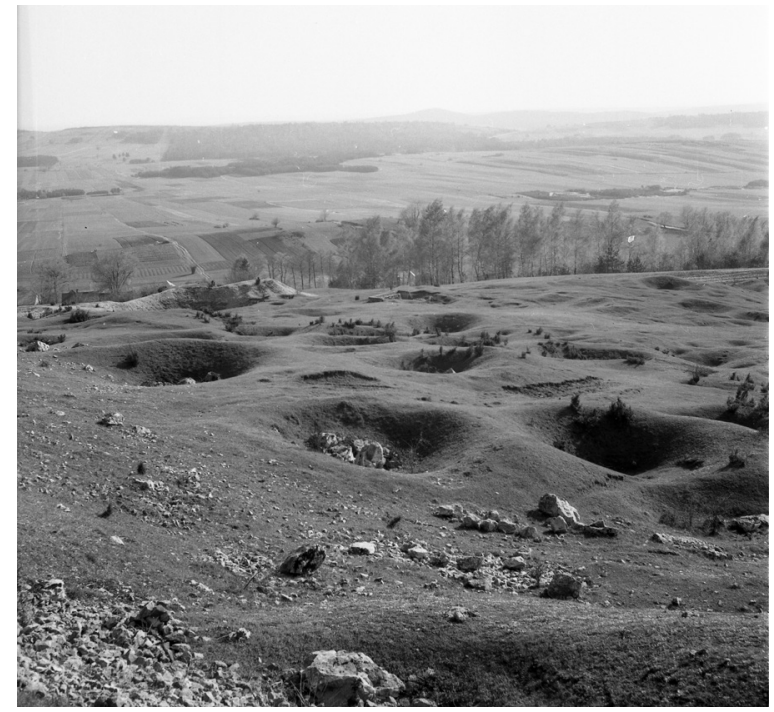

Il. 1. Pole górnicze na zachodnim stoku góry Miedzianka (gm. Chęciny), widoczne liczne zagłębienia terenu powstałe podczas eksploatacji rud miedzi metodą wieloszybikową od XV do XVIII wieku. Fot. J. Fijałkowski, 1969, MNKi/Pf/1846 (dzięki uprzejmości Muzeum Narodowego w Kielcach)

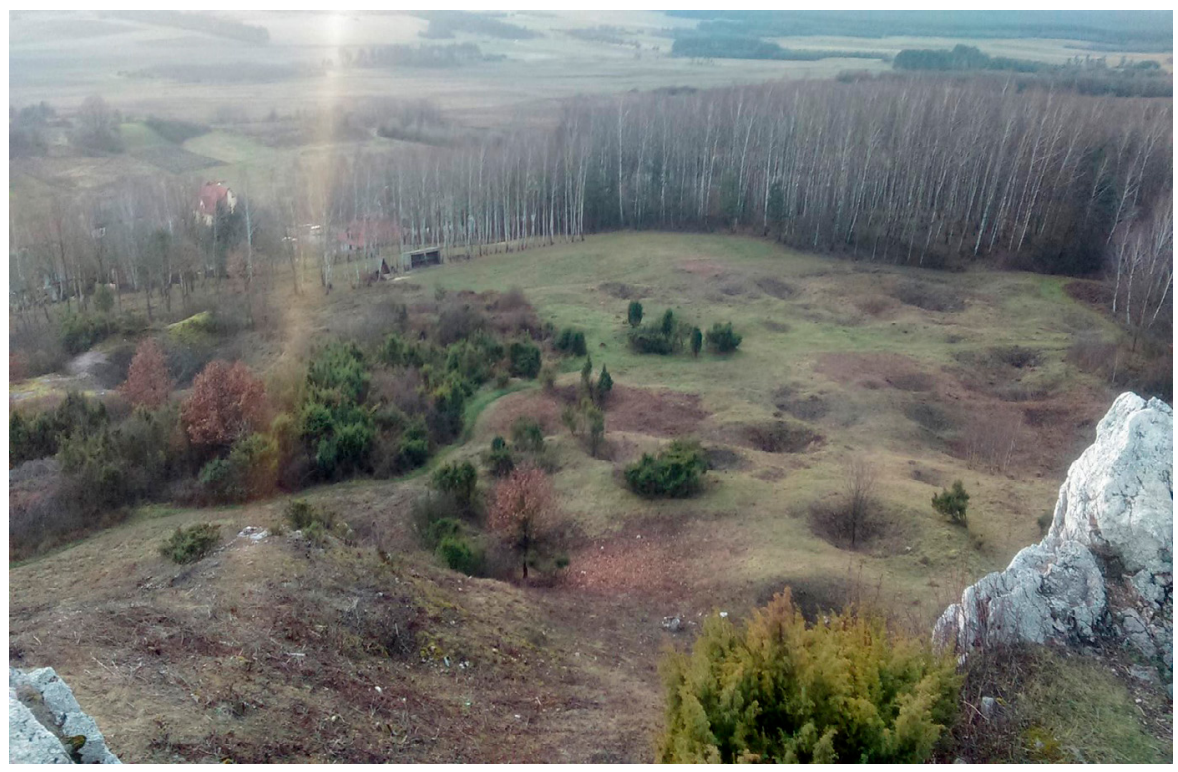

Il. 2. Pole górnicze na zachodnim stoku góry Miedzianka (gm. Chęciny), widoczne liczne zagłębienia terenu powstałe podczas eksploatacji rud miedzi metodą wieloszybikową od XV do XVIII wieku, stan obecny. Fot. R. Siuda (dzięki uprzejmości autora) 


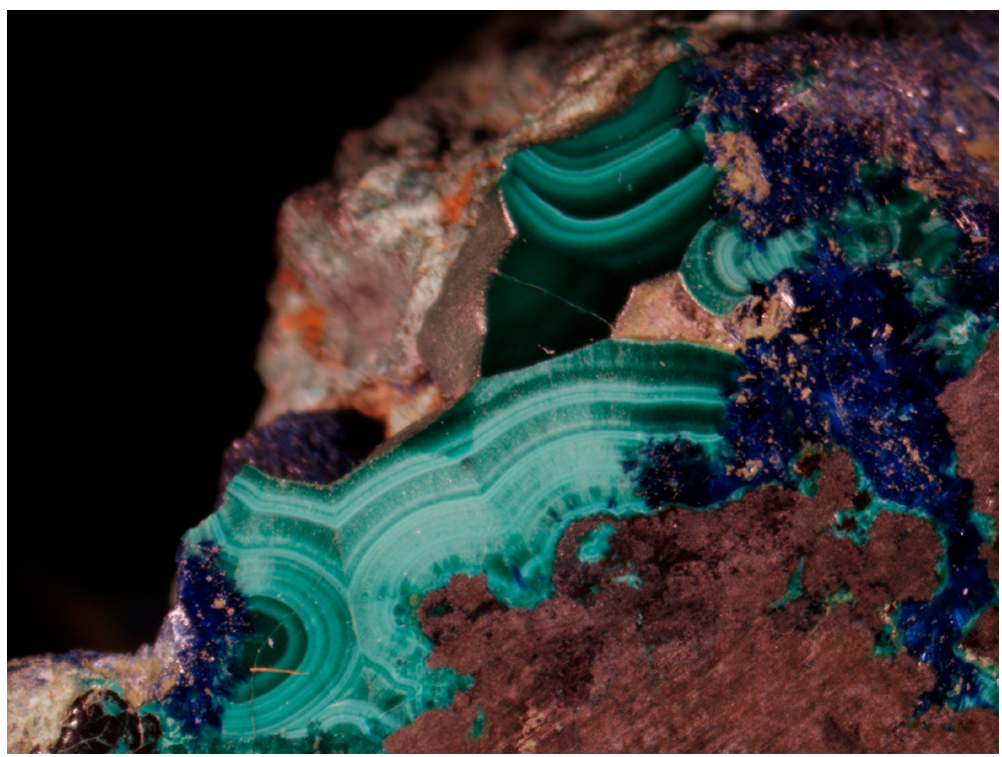

Il. 3. Masywny zielony malachit o koncentrycznej budowie przerastający się z niebieskim azurytem na powierzchni chalkozynu; Miedzianka, Góry Świętokrzyskie. Fot. R. Siuda (dzięki uprzejmości autora)

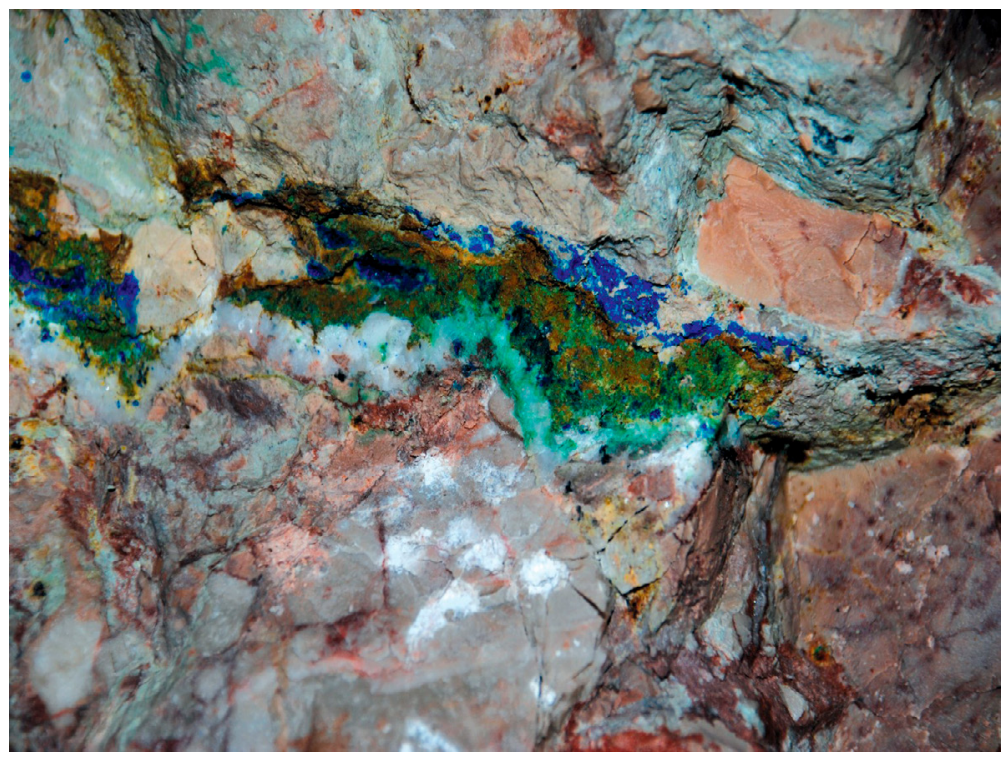

Il. 4. Zielony malachit i niebieski azuryt zastępujące żyłę kruszcową, zbudowaną z chalkopirytu i tennantytu, przecinającą wapienie dewonu. Ocios chodnika górniczego w kopalni Zofia; Miedzianka, Góry Świętokrzyskie. Fot. R. Siuda (dzięki uprzejmości autora) 


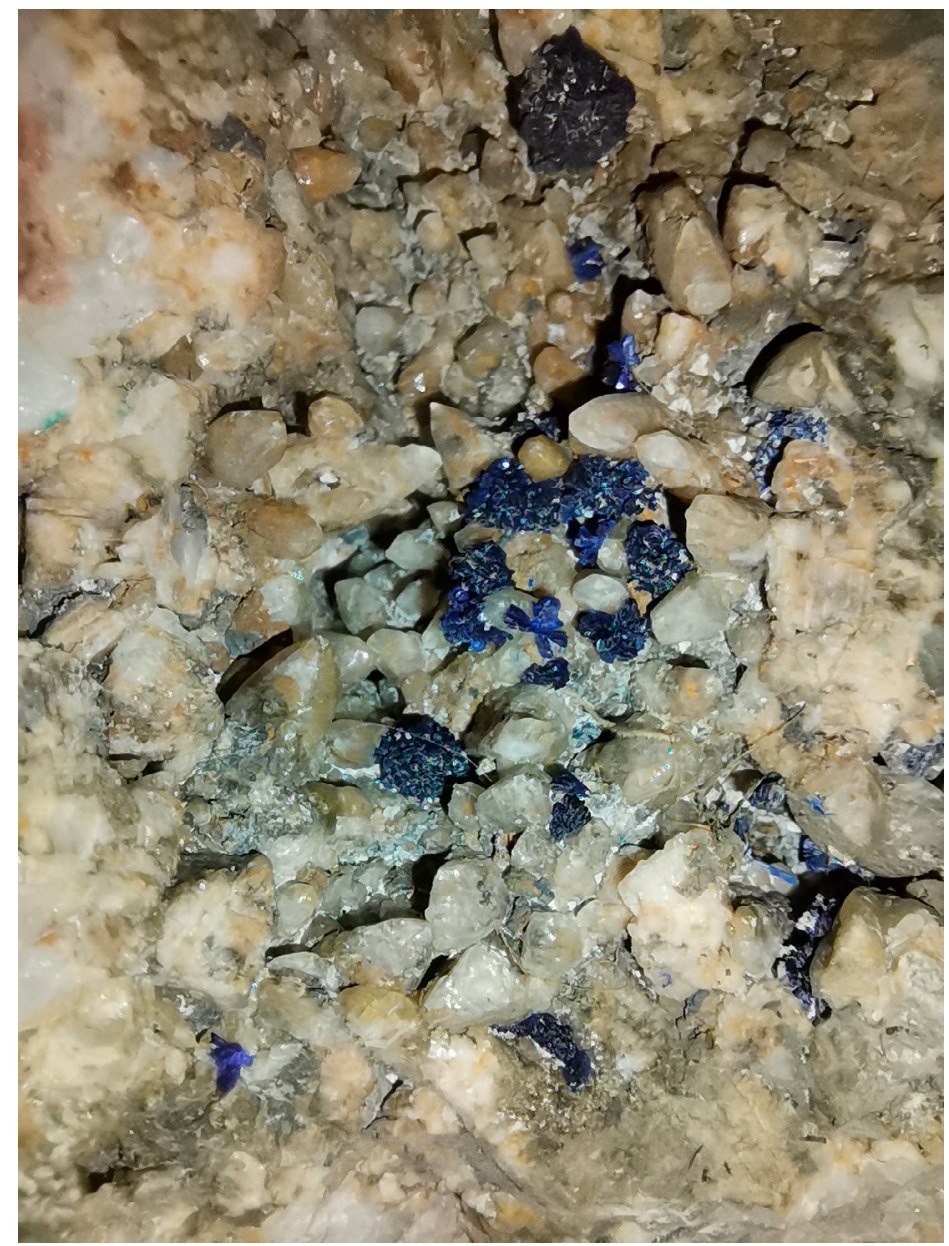

Il. 5. Kryształy azurytu na wapieniu, Miedzianka, Góry Świętokrzyskie. Fot. I. Sekudewicz (dzięki uprzejmości autorki) 


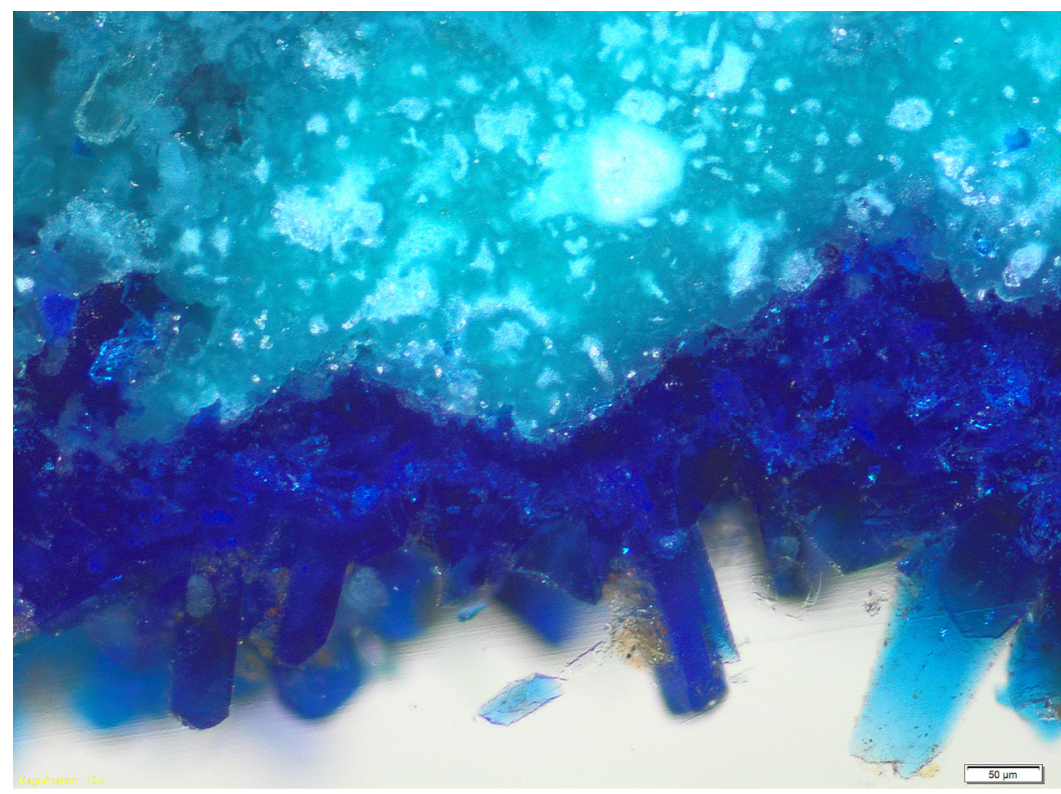

Il. 6. Ciemnoniebieskie kryształy azurytu z Miedzianki świętokrzyskiej w przekroju poprzecznym. Fot. S. Svorová Pawełkowicz

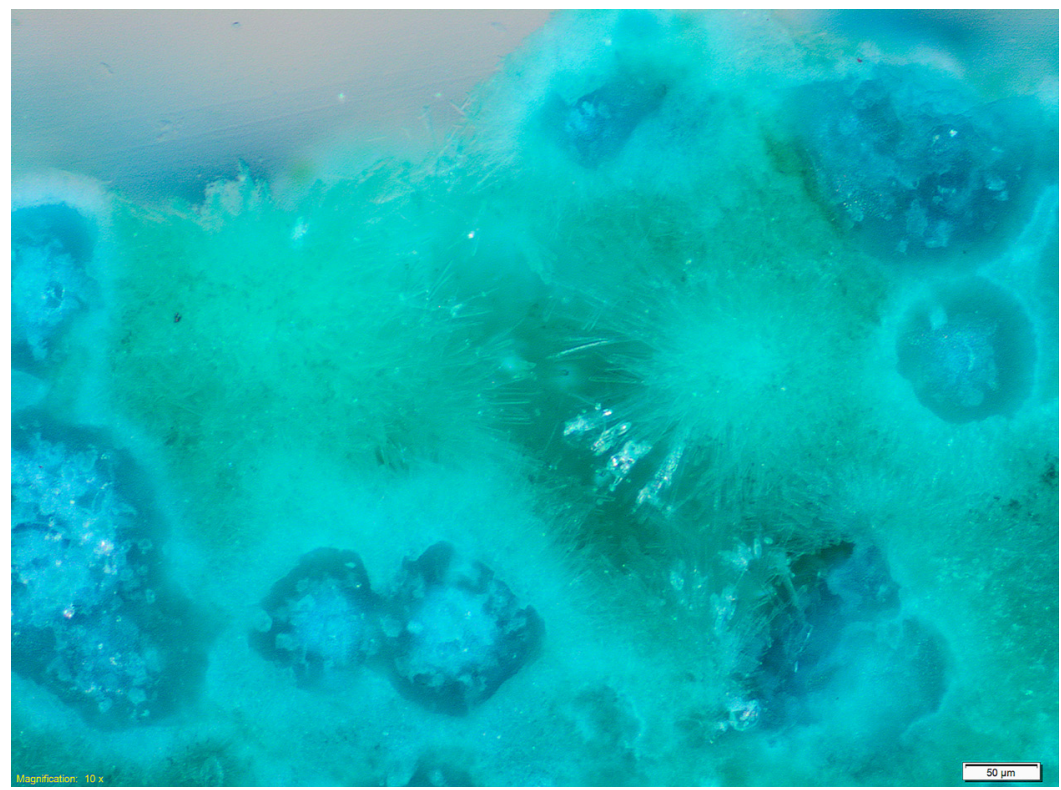

Il. 7. Skupiska igiełkowatych kryształów malachitu z Miedzianki świętokrzyskiej w przekroju poprzecznym. Fot. S. Svorová Pawełkowicz 


\section{Bibliografia}

\section{Źródła}

Kielce, Archiwum Państwowe (AP):

Zespół Komisji Województwa Krakowskiego, sygn. 86.

Kraków, Archiwum Kurii Metropolitalnej (AKMK):

Acta Officialia Cracoviensia, 47, fol. 1080.

Kraków, Archiwum Narodowe (AN):

Akta miasta Krakowa, sygn. 432, s. 1036.

Warszawa, Archiwum Główne Akt Dawnych (AGAD):

Metryka Koronna, Lustracje, sygn. 19, k. 148v; sygn. 19, fol. 156v; sygn. 29, k. 180r; sygn. 29, k. 185v; sygn. 36, k. 98r; sygn. 69, k. 213r.

Archiwum Skarbu Koronnego, sygn. 43, s. 3.

\section{Opracowania}

„Analyse de l'histoire naturelle de Pologne du P. Gab. Rzączyński.” W Jean-Baptiste Dubois, Essai sur l'histoire littéraire de Pologne, 401-520. Berlin: G. I. Decker imprimeur du roi, 1778.

Atlas minor Gerardi Mercatoris à I. Hondio plurimi æneis tabulis auctus atque illustrates. Dordrecht: Excudebat Adrianus Bottius, 1610.

Auctuarium historiae naturalis curiosae Regni Poloniae, Magni Ducatus Lithuaniae, annexarumque provinciarum, per P. Gabrielem Rzączynski Soc. Jesu. concinnatum. Opus pothumum cum permissu superiorum. Gdańsk: [s.n.], 1745.

Bąkowski, Klemens. Zamek krakowski. Kraków: Spółka Wydawnicza Polska, 1913.

Carosi, Jan F. „List trzeci. Z Kielc, 15 Sierpnia.” W [Jan F. Carosi,] „Podróż przez niektóre prowincye polskie.” Magazyn Warszawski 2 (1784): 302-314.

Długosz, Jan. Roczniki, czyli Kroniki sławnego Królestwa Polskiego. Ks. 1, ks. 2 do 1038. Red. Jan Dąbrowski. Tłum. Stanisław Gawęda. Przedmowa Wanda Semkowicz-Zarembina. Warszawa: Wydawnictwo Naukowe PWN, $2009^{2}$.

Eastaugh, Nicholas, Valentine Walsh, Tracey Chaplin, i Ruth Siddall. The Pigment Compendium. A Dictionary and Optical Microscopy of Historical Pigments. Oxford: Butterworth-Heinemann, 2008.

Fabiański, Marcin. Zamek króla Zygmunta I na Wawelu. Architektura - dekoracja architektoniczna - funkcje. Kraków: Zamek Królewski na Wawelu - Państwowe Zbiory Sztuki, 2017.

Gadomski, Jerzy. Gotyckie malarstwo tablicowe Małopolski. T. 3 1500-1540. Warszawa: Państwowe Wydawnictwo Naukowe, 1995.

Gwagnin, Aleksander. Sarmatiae Europeae descriptio, quae Regnum Poloniae, Lituaniam, Samogitiam [...] partem complecitur. Kraków: Maciej Wirzbięta, [po 20 VI 1578]. 
Helbig, Herbert. „Cramer v. Claußbruch.” W Neue Deutsche Biographie. T. 3 Bürklein-Ditmar, red. Otto Graf zu Stolberg-Wernigerode, Erich Angermann, i Karl Otmar Frhr. V. Aretin, 392-393. Berlin: Duncker \& Humblot, 1957. Dostęp 2 maja 2021. https://daten.digitale-sammlungen.de/0001/bsb00016319/images/index. html?id=00016319\&groesser $=\&$ fip=193.174.98.30\&no= \&seite $=407$.

Kmieć, Heliodor. Dzieje techniki zbrojeniowej nad rzeka Bobrza i w jej okolicach od XVI do XIX wieku. Kielce: Regionalny Ośrodek Studiów i Ochrony Środowiska Kulturowego, 2000.

Kowalczewski, Zbigniew. „O surowcach mineralnych i rozwoju górnictwa w okolicach Chęcin.” W VII wieków Chęcin. Materiały sesji naukowej 24 V 1975, red. Zenon Guldon, 91-99. Kielce: Wyższa Szkoła Pedagogiczna w Kielcach / Urząd Miasta i Gminy w Chęcinach, 1976.

Kroker, Ernst. „Heinrich Cramer von Claußbruch, ein Leipziger Handelsherr des 16. Jahrhunderts.” W Quellen zur Geschichte Leipzigs. T. 2, red. Gustav Wustmann, 355-386. Leipzig: Duncker \& Humblot, 1895. Dostęp 2 maja 2021. https://digital. slub-dresden.de/werkansicht/dlf/91859/371/.

Król, Paweł, i Jan Urban. Geologiczne i historyczne dziedzictwo górnictwa miedzianogórskiego. Kielce: Agencja “JP” s.c., 2012.

Król, Paweł, i Jan Urban. „Kopalnie w Miedzianej Górze i w Ławęcznej oraz ochrona ich pozostałości.” Rocznik Świętokrzyski. Seria B - Nauki Przyrodnicze 29 (2003): 1-44.

Kumor, Bolesław Stanisław. Dzieje archidiecezji krakowskiej do roku 1795. T. 1. Red. Jacek Urban. Kraków: Wydawnictwo św. Stanisława BM Archidiecezji Krakowskiej, 1998.

Kutrzeba, Stanisław. „Wypowiedź w sprawie listów Zygmunta I do Stanisława Szafrańca w sprawie chęcińskiego lazuru.” Sprawozdania Komisyi do Badania Historyi Sztuki w Polsce 7, z. 3 (1903): CCXXVIII-CCXXIX.

Linde, Samuel Bogumił. Słownik języka polskiego. T. 1, cz. 2 G-L. Warszawa: Drukarnia XX. Piiarów, 1808.

Lustracje dóbr królewskich XVI-XVIII wieku. [T. 1] Małopolska. [Cz. 1] Lustracja województwa sandomierskiego: 1564-1565. Oprac. Władysław Ochmański. Wrocław-Warszawa-Kraków: Państwowe Wydawnictwo Naukowe, 1963.

Łabęcki, Hieronim Hilary. Górnictwo w Polsce: opis kopalnictwa i hutnictwa polskiego pod względem technicznym, historyczno-statystycznym i prawnym. T. 1. Warszawa: Drukarnia Juljana Kaczanowskiego, 1841.

Łopaciński, Hieronim. „Wiadomości o marmurach w Polsce z rękopisów oraz dzieł dawnych i nowszych.” Sprawozdania Komisyi do Badania Historyi Sztuki w Polsce 7, z. 1-2 (1902): 582-595.

Martini Cromeri Polonia sive De situ, populis, moribus, magistratibus et republica regni Polonici libri duo, 1578. Wyd. Wiktor Czermak. Kraków: Akademia Umiejętności, 1901.

Mazur, Hubert. „Źródła do dziejów Chęcin w zasobie Archiwum Państwowego w Kielcach.” Między Wisłą a Pilicq 12 (2011): 165-200. 
Molenda, Danuta. „Eksploatacja rud miedzi i handel miedzią w Polsce w późnym średniowieczu i w początkach nowożytności (do 1795 r.).” Przegląd Historyczny 80, z. 4 (1989): 801-814.

Molenda, Danuta. „Górnictwo chęcińskie w XVI i XVII wieku i jego związki z górnictwem śląsko-krakowskim.” W Dzieje i technika świętokrzyskiego górnictwa i hutnictwa kruszcowego. Materiały z sesji naukowej odbytej z okazji jubileuszu IX wieków Kielc 16 listopada 1970 roku, red. Zbigniew Kowalczewski, 107-120. Warszawa: Wydawnictwa Geologiczne, 1972.

Niemcewicz, Julian Ursyn. Podróże historyczne po ziemiach polskich między rokiem 1811 a 1828 odbyte. Paryż: Księgarnia A. Francka / Petersburg: Księgarnia B. M. Wolffa, 1858.

Osiński, Józef. Opisanie polskich żelaza fabryk, w którym świadectwa Historyków wzmiankujących miejsca Minerałów przytoczone; Przywileie nadane szukającym Kruszców w całości umieszczone; początek wyrabiania u nas żelaza odkryty; Rudy Kraiowey czterdzieści ośm gatunków w kolorach właściwych wydane i w szczególności wyłożone; Piece i Dymarki w całym Krolestwie znayduiące się wyliczone; z żelaza Kraiowy zysk okazany; Słownik Kuźniacki, oprócz wyrazów Technicznych, wiele wiadomości zawierający przydany. Warszawa: Druk. IKM i Rzeczypospolitey u XX. Scholarum Piarum, 1782.

Paulewicz, Marian. Chęcińskie górnictwo kruszcowe od XIV do połowy XVII wieku. Kielce: Kieleckie Towarzystwo Naukowe, 1992.

Petri Bertii Geographischer eyn oder zusammengezogener Tabeln Fünff uterschiedliche Bücher. Franckfurt: Heinrich Lorentzen, Matth. Becker, 1612.

Piasecki, Paweł. Chronica gestorum in Europa singularium. Kraków: In Officina Typographica Francisci Cæsarii, 1645.

Ptaśnik, Jan. „Lazur polski z Chęcin w XV w.” Prace Komisii Historii Sztuki 1, z. 2 (1919): XXVIII.

Rachunki do budowy zamku krakowskiego 1530. Oprac. Marek Ferenc (Źródła do Dziejów Wawelu 18). Kraków: Zamek Królewski na Wawelu - Państwowe Zbiory Sztuki, 2006.

Rachunki dworu królewskiego 1544-1567. Oprac. Adam Chmiel (Źródła do Historyi Sztuki i Cywilizacyi w Polsce). Kraków: Akademia Umiejętności, 1911.

Rachunki podskarbiego Andrzeja Kościeleckiego z lat 1510-1511. Oprac. Anna Wajs i Hubert Wajs (Źródła do Dziejów Wawelu 15). Kraków: Zamek Królewski na Wawelu, 1997.

Rachunki wielkorządowe Jana Bonera 1558. Oprac. Józef Garbacik (Źródła do Dziejów Wawelu 7). Kraków: Nakładem Ministerstwa Kultury i Sztuki, 1974.

Rastawiecki, Edward. Słownik malarzów polskich tudzież obcych w Polsce osiadłych lub czasowo w niéj przebywających. T. 2. Warszawa: Nakładem autora w drukarni S. Orgelbranda, 1851.

Reinhold, Josef. Polen / Litauen auf den Leipziger Messen des 18. Jahrhunderts. Weimar: H. Bohlaus, 1971. 
Sobieszczański, Franciszek Maksymilian. „Wycieczka archeologiczna w niektóre strony guberni radomskiej odbyta w miesiącu wrześniu r. z. (dokończenie).” Biblioteka Warszawska. Pismo poświęcone naukom, sztukom i przemysłowi 2 (1852): 28-68.

Szelińska, Wacława. „Chorographia Regni Poloniae” Jana Długosza. Kraków: Wydawnictwo Naukowe Wyższej Szkoły Pedagogicznej w Krakowie, 1980.

Śniadecki, Jędrzej. Początki chemii dla użycia słuchaczów akademickich ułożone. T. 2. Wilno: Józef Zawadzki, 1807.

Teka Grona Konserwatorów Galicyi Zachodniej. T. 5 Wawel. T. 2 Materyały archiwalne do budowy zamku. Oprac. Adam Chmiel. Kraków: Drukarnia Uniwersytetu Jagiellońskiego pod zarządem J. Filipowskiego, 1913.

Unger, Manfred. „Georg Winter.” W Sächsische Biografie, oprac. Institut für Sächsische Geschichte und Volkskunde e.V. Online-Ausgabe. Dostęp 2 maja 2021. https://saebi. isgv.de/biografie/Georg_Winter_(um_1551-1618).

Unger, Manfred. „Heinrich Cramer von Claußbruch.” W Sächsische Biografie, oprac. Institut für Sächsische Geschichte und Volkskunde e.V. Online-Ausgabe. Dostęp 2 maja 2021. https://saebi.isgv.de/biografie/Heinrich_Cramer_von_Clau\%C3\%9Fbruch_(1515-1599).

Watin, Jean-Félix. L'art du peintre, doreur et vernisseur, ouvrage utile aux artistes et aux amateurs qui veulent entreprendre de peindre, dorer et vernir toutes sortes de sujets en bâtimens, meubles, bijoux, equipages, etc.... Paris: Grangé, Durand, Watin, 1773.

Wypisy źródłowe do dziejów Wawelu z archiwaliów kapitulnych i kurialnych krakowskich 1516-1525. Oprac. Bolesław Przybyszewski (Źródła do Dziejów Wawelu 5). Kraków: Ministerstwo Kultury i Sztuki, 1970.

Wypisy źródłowe do dziejów Wawelu z archiwaliów kapitulnych i kurialnych krakowskich 1530-1533. Oprac. Bolesław Przybyszewski (Źródła do Dziejów Wawelu 11). Kraków: Ministerstwo Kultury i Sztuki, 1986. 